\title{
THE SYSTEM OF PROTECTION OF STUDENTS FROM INTERNAL THREATS
}

\author{
Hulkarhon Muhammadjanovna Jumaeva
}

Teacher, Termez State University, Uzbekistan

Yusufkhon Ganievich Makhmudov

Ph.D., Professor, Termez State University, Uzbekistan

\section{ABSTRACT}

The article focuses on the pedagogical system of protecting students from internal threats. Objective information about the social health of students, as well as the need for a qualitatively new approach to solving problems in the field of spiritual support for its comprehensive development and the "cleansing" of the spiritual environment of young people. Today, students are shown the skills, knowledge and competencies to prepare for professional activities, to develop immunity to internal threats. The components of the structure of protection of students from internal threats: purposefulness, initiative, patriotism, conviction, willpower, responsibility and conscientiousness are claimed. The lexical meanings of these components are also covered.

KEYWORDS: -Protection of students from internal threats, pedagogical system, components of protection of students from internal threats, purposefulness, initiative, patriotism, conviction, willpower, responsibility, conscientiousness.

\section{INTRODUCTION}

In the world, The education of the younger generation is one of great importance around the world. Because the effectiveness of systemic reforms in all areas, which are deeply rooted in the process of globalization, as well as the degree to which such a very responsible and important task as the future is sustainable and depends on the morale of students. The inner spirituality of the students is a priority in this regard. Therefore, it is necessary to understand that the issue of educating students in the spirit of resilience to internal threats should be postponed or looked at from the sidelines, as a kind of abstract or self-fulfilling prophecy.

In our country, increasing the spiritual and intellectual potential of students through education is one of the key factors in the development of society.

In this regard, the Strategy of Actions for the Further Development of the Republic of Uzbekistan states: "The main task is to bring up physically healthy, mentally active, intellectually developed, independent-minded, strong-minded students, loyal to the motherland, deepen democratic reforms and increase their social activity in the development of civil society " [1. 
CURRENT RESEARCH JOURNAL OF PEDAGOGICS 2(8): 122-126, August

2021 DOI: https://doi.org/10.37547/pedagogics-crjp-02-08-26

ISSN 2767-3278

(C)2021 Master Journals

\section{Crossref doi) 81 Google}

Accepted $26^{\text {th }}$ August, 2021 \& Published 31 th August, 2021

70-m.]. In order to fulfill that task, it is an important to enrich the mental and spiritual world of students, strengthen measures to develop the ability to withstand internal threats, identify effective factors and expand their application in educational activities.

Protecting students from internal threats is one of the key components of special professional competence.

Therefore enriching students' spirituality, filling spiritual gaps, cultivating in students such qualities as self-expression, dignity, self-sacrifice, perseverance, responsibility, creativity, development should be considered as an integral part of the educational process.

Strengthening the status and spiritual and moral potential of students as individuals can be considered as a key strategy in the system of ensuring the spiritual security of society. In turn, these strategies are based on a comprehensive understanding of student problems and the implementation of a number of measures: to achieve an equal system of declared rights and opportunities for students and their professional self-awareness and the creation of an effective system of actions to bridge the gap between existing systems.

In overcoming internal threats in students, it is important to consider them as a category that reflects their social health, value hierarchy, and spiritual condition in general.

Objective information on the social health of students, as well as spiritual support for its comprehensive development and need for a qualitatively new approach to solving problems in the field of "cleaning" the spiritual environment of young people. In this case, it is advisable for students to have an independent position. Because the conflicting conditions in the development of students who are unable to combine their social aspirations and needs as opportunities to meet their needs as a subject are a key factor in reducing their activity. These factors, in turn, lead to increased internal threats such as uncertainty and indifference in student activity. In our opinion, in protecting students from internal threats, first of all, they should reflect the following aspects:

1) understanding the content and essence of such concepts as internal threat and spiritual threat;

2) be able to apply the basic terms of spirituality in life and educational situations in their place, orally or in writing;

3) be able to analyze the internal threat in terms of its individual and social interests;

4) be able to explain the laws of spirituality and its application;

5) be able to find optimal solutions to problems that may arise in ordinary and unusual, life and educational situations;

6) be able to analyze and use our national and spiritual heritage;

7) explain the relationship of spirituality with other areas of professional and educational life.

Today, preparing students for professional activities, improving in them immunity to internal threats, requires the development of skills, knowledge and competencies. The urgency of that task can be justified by the following social factors:

1) the impact of internal threats on the consciousness and thinking of students, its prospects hinder the development of society;

2 ) increased interest of students in new forms of "fake spirituality" (various games).

Claimed on the above factors, the components of protecting students from internal threats have been identified based on three common areas of personality development in pedagogy (cognitive, 
CURRENT RESEARCH JOURNAL OF PEDAGOGICS 2(8): 122-126, August

2021 DOI: https://doi.org/10.37547/pedagogics-crjp-02-08-26

ISSN 2767-3278

(C)2021 Master Journals

\section{Crossref do) 81 Google}

Accepted $26^{\text {th }}$ August, 2021 \& Published 31 th August, 2021

affective, behavioral).

The following are the components of a structure to protect students from internal threats:

1. Purposefulness- is a reflection of the individual's harmonization of needs with the norms of society, the readiness of the individual in a valuable device to implement this system of relations in practice. It is explained by goal orientation and planning, development and evaluation of ideas, productivity of actions, solving problem situations.

2. Support of patriotic feelings in students: strengthening social institutions - families and schools as the main place of protection from internal threats; one of the strongest means of internal threat to the consciousness and behavior of modern students is to ensure the values and priorities of popular culture, limiting the destructive influence of the media.

3. The formation of a healthy lifestyle in students. It is determined by the extent to which students are responsible for their own health, harmony with the environment, their own organism. A person's careful attitude to his own health, his ability to avoid the factors that cause illness, is especially valued as one of the good qualities of a person. A healthy lifestyle - means eating good, vitamin-rich foods, engaging in regular physical activity, following a sequence of work and rest, living in harmony with nature, and avoiding excessive luxuries. Such a lifestyle depends on environmental thinking and the level of development of society.

4. The results of the study showed that the protection of students from internal spiritual threats is primarily associated with the formation in them of the qualities of initiative. It shows that in the context of mass education, it is necessary to develop the qualities of initiative in students in order to protect them from internal threats. It is known that resourceful, enterprising students can exhibit these characteristics in a variety of activities, depending on their psychological characteristics. Success, the quality of initiative can serve as a guarantee of successful protection of students from internal threats. On the other hand, are not only spiritually mature, but also devotees of science, art, culture, politics, and other fields. In this regard, A.M. Omarov claimed that "initiative is a broad and forward-thinking, enthusiastic, persistent in decision-making, the ability to take risks" [8; 240-p.].

Psychologist R. Khizrach does not deny initiative in overcoming internal threats and describes it as follows. "Entrepreneurship - is characterized, first of all, by the definition of independence of thought, non-standard, sense of selfdetermination, ability to take risks [9; 137-p.].

In the explanatory dictionary of the Uzbek language "the initiator - manager, the owner of the initiative"; "Initiative - the work of initiative, initiator; to be a pioneer in a work "[11; 19-p.].

Entrepreneurship- is the ability of an individual to easily establish and maintain positive relationships in communication, to be ready to interact with others, and to have organizational qualities.

5. In the explanatory dictionary of the Uzbek language it is defined as "firmness - possession of firmness " [11; 266-p.]. Hence, perseverance - is associated with an individual's willingness to take risks, independence and responsibility. Independence - is interpreted as the ability to identify and shape a problem, set a goal, and determine ways to achieve it without regular supervision and the help of others.

6. Responsibility means that a person acquires a social necessity and consciously adheres to the moral principles and legal norms set by society. Responsibility as a personality trait is formed in the process of joint activity in which social 
CURRENT RESEARCH JOURNAL OF PEDAGOGICS 2(8): 122-126, August

2021 DOI: https://doi.org/10.37547/pedagogics-crjp-02-08-26

ISSN 2767-3278

(C)2021 Master Journals

\section{Crossref doi) 81 Google}

Accepted 26 $6^{\text {th }}$ August, 2021 \& Published 31 $1^{\text {th }}$ August, 2021

values, norms and rules are formed [10; 356-p.].

7. Patriotism - is a concept that expresses people's love and devotion to their homeland. Patriotism is a universal feeling, one of the spiritual values that has been polished for centuries, which is common to all people, peoples, nations. Historically, patriotism- is also a set of emotions that people have developed in the process of social development related to the fate of their homeland, the struggle of peoples for the inviolability and independence of the territory in which they live. It is reflected in the pride of the country's past and present, in the protection of its interests [7; P. 30-35].

8. Belief - the most important and fundamental fixed concepts, perceptions and science, formed by an individual, community, group, society on the basis of firm belief in certain ideas, values and norms, without hesitation, without doubt, their active mental and emotional acceptance, to do, to love, to be devoted to them, to be loyal to them, to adapt their ideals, social aspirations and practices "[7; 29-p.].

9. Conscientiousness - is a spiritual and moral concept for man. Conscience means (Arabic "vajada" (finding)) is the inner world of man, himself and his spiritual strength. Conscience - is a set of person emotions, such as feelings, reactions, desires, love for something, hatred, inclination, disliked, spiritual enjoyment or pain.

10. Willpower - a concept of human nature, which means perseverance, the ability to control their will, to resist various passions.

Willpower means "to ask, to demand, to choose, to prefer". Willpower is an inner force that motivates a person to do or not to do anything.

In other words, the willpower is the power to control people's actions and behavior [5; 38-p.]. On turn, willpower is "the ability to think and decide consciously, as well as the power to pick and choose one of the ways to do so equally".
Willpower is an important component of protecting students from internal threats. Believing that the quality of willpower has an effective power in defending against an internal threat sets the first condition for success in this regard. The only weapon in internal threats is willpower. He/She destroys his/her inner enemy like emptiness, laziness and indifference. It is impossible to show any example of success from a person with a weak willpower, because to be successful is to work hard. Labor is a form of volitional quality. Diligence - is the result of preparation.

A.F. Boshgil evaluates volitional behavior that differs from human instinctive behavior, habit and imitation. Emphasizing that willpower is the main distinguishing feature of human beings, he describes it as follows:

Once the internal threat has taken root and negative behaviors have formed, the impact of educational actions becomes increasingly difficult and patience is required to achieve the result. In this regard, the development of volitional qualities in students guarantees the achievement of goals.

The relevant specific personal characteristics regarding the components that need to be structured in protecting students from internal threats have a conditional description. All personality traits are interrelated.

It is the development of personality traits in students that emerges as a factor in overcoming internal threats.

\section{REFERENCES}

1. Decree of the President of the Republic of Uzbekistan dated February 7, 2017 No. PF4947 "On the Action Strategy for further development of the Republic of Uzbekistan". Collection of Legislation of the Republic of 
CURRENT RESEARCH JOURNAL OF PEDAGOGICS 2(8): 122-126, August

2021 DOI: https://doi.org/10.37547/pedagogics-crjp-02-08-26

ISSN 2767-3278

(C)2021 Master Journals

Crossref do: 81 Google

Accepted $26^{\text {th }}$ August, 2021 \& Published 31 th August, 2021

Uzbekistan, 2017, No. 6, Article 70.

2. Sh.M.Mirziyoev "Let us work harder and more resolutely for the fate and future of our country". -T: Uzbekistan, 2017. -21 p.

3. I.A. Karimov "Serving for the happiness and great future of our motherland is the highest happiness. - T: “Uzbekistan”, 2015. -120 p.

4. M.B.Artiqova "Development of entrepreneurial skills in students on the basis of secondary school and family partnership." Written dissertation for the degree of Doctor of Pedagogical Sciences (DSc). 2018. -165 p.

5. 5.M.Z. Aydin, Gürler Akyol Sh., 2013. -38 p.

6. Pedagogy. Under the general editor of M.Kh.Tokhtakhodjaeva. - T. National Society of Philosophers of Uzbekistan, 2010. - 45 p.

7. A.I. Kuznetsova "Culture and processes of globalization // Power. - 2009. - No. 1. - p. 3031.

8. Omarov A.M. "Management: the art of communication / -Moscow, 1993.240 p.

9. R.Khizrach , M.Peters "Entrepreneurship, or how to start your own business and achieve success". - Moscow, 1991.-137 p.

10. D.N.Ushakov "Explanatory dictionary of the modern Russian language "/ -Moscow: Adelant, 2013. - 800 p, -P. 356

11. The explanatory dictionary of the Uzbek language / -T. National encyclopedia of Uzbekistan, 2005. -P. 266 - 321.

12. H.M.Djumayeva, "Some shapes of spiritual attack, its influences and outcomes for educating the youth", Europen journal of Research snd Reflection in Educational Sciences. Research. № 2. 2020.8.-P. 20-23.

13. H.M.Djumayeva, "Model of protection of students from internal threats and its main components Model of protection of students from internal threats and its main components", Europen journal of Research snd Reflection in Educational Sciences. Research. № 12. 2020.8.-P. 94-99. 